\title{
Phytoplankton and Nutrient Dynamics of a Tropical Estuarine System, Imo River Estuary, Nigeria
}

\author{
Akoma, Osondu C.
}

\begin{abstract}
This paper reported a fifteen month study of the patterns of variation of phytoplankton, physical and chemical characteristics of the Imo River estuary between April 2001 and June 2002 were reported. There were remarkable spatial and temporal variations of physico-chemical parameters and significant difference in the stations $(p<0.05)$. A wide array of phytoplankton species distributed in 221 taxa, 85 genera, 37 families, 16 orders in 7 divisions; with chlorophyta $>$ bacillariophyta $>$ Cyanophyta $>$ Dinophyta $>$ Euglenophyta $>$ Chrysophyta $>$ Rhodophyta. Phytoplankton density and diversity were highest in the brackish water, mesohaline zone of the estuary. The trend of wet season nutrient enrichment was observed and maximum phytoplankton concentration was however not coincidental with nutrient enrichment. Early dry season assemblages were characterized by relatively large number of chlorophyta and pennate diatoms in the freshwater and brackishwater zones of the estuary. The dynamic throughput of the estuary is a function of seasonal nutrient input and the effect of the adjacent sea on the estuary.
\end{abstract}

\section{Introduction}

Estuaries are harsh ecosystems subject to highly variable environmental conditions like tidal amplitudes and salinity. They are sites of major industries and repositories for numerous effluents. Organisms able to colonize estuaries have evolved mechanisms that allow them to survive variable salinities, long periods of immersion and emersion and in some instances, a degree of pollution. An estuary is a semi enclosed coastal body of water that has a free connection with the open sea. It is strongly affected by tidal action, and within it seawater is mixed and diluted with freshwater from land drainage (Lee, 1989). Estuaries are among the most complex bodies of water encountered by the limnologist and they are the most productive. The dominant features of an estuary are, variable salinity, a salt wedge or 
interphase between salt and freshwater and often large area of shallow turbid water overlying mud flats, salt marshes and mangrove swamps (Odum, 1977). Increased human activities, industrialization and urbanization have put a lot of pressure on the estuarine habitat. These activities have direct effect on the water quality, quantity and quality of phytoplankton and other biocoenoses.

Reports on some tropical estuaries include those of Edward and Ayyakkanu (1991) on the Kollidan estuary, southeast coast of India, Jiyalal-Ram (1991) on the Mahi estuary and Ramaiah and Ramaiah (1998) on the polluted Bombay harbor-Thana-Bassein Creek estuarine complex. In Africa some researches had been reported and they included the early work of Prowse and Talling (1958) on the seasonal growth and succession of phytoplankton in the White Nile, Woodhead and Tweed $(1958,1960)$ on some brackish environment in the West African coast including Ghana, Cote d'Ivoire, Sierra Leone, Liberia, Republic of Benin among others and Mohammed, Ahmed and Zainab (1988) on the Nile system in Egypt. Caljon (1987) investigated a landlocked brackish lagoon of Lake Tanganyika; Affinito, Fumanti and Ricci (1989) reported some aspects of the phytoplankton of rivers in Sierra Leone. Notable estuarine studies in Nigeria included Nwadiaro and Ezefili (1986) on the New Calabar River; lower Niger Delta, Opute (1991) on the Warri/Forcados estuary, southern Nigeria, Nwankwo (1998) on the Epe lagoon, Lagos, Kadiri (1999a) on the coastal waters of Nigeria and Akpan Offem and Nya (2002) reported baseline ecological studies of the Great Kwa River, southern Nigeria.

The Imo River is one of the major rivers in the southeastern part of Nigeria. The estuary is located between latitudes $4^{\circ} 15^{\prime}, 4^{\circ} 59^{\prime}$ North of the Equator and longitudes $7^{\circ} 20^{\prime}, 7^{\circ} 45^{\prime}$ East of Greenwich Meridian. Its length from source to mouth is about $215 \mathrm{~km}$. The river originates on the Achi Okigwe highlands in the southern elevation of the Udi Hills. The source is dendritic. The river flows through coastal plain, alluvium and mangrove swamp and empties into the Atlantic Ocean through the Opobo Creek at the Bight of Biafra. The two major tributaries Otamiri and Aba Rivers drain into the river and play a 
major role in the hydrology of the Imo River estuary. Considering all the different potential roles water has as a resource, optimization is best achieved through a combination of uses. Conflicts over use of water exist with industrial development as industry needs to discharge waste economically and hence use rivers as natural drain. At the same time, industrial areas tend to be areas of high population density which have correspondingly high demand for safe, potable water (Spiro and Stigliani, 2003).

This paper aims to show the distribution of phytoplankton and the changes in physico-chemical parameters in relation to nutrient concentration in an estuarine system. It provides background information on the physical, chemical, trophic status and phytoplankton composition of the estuary.

\section{Methodology}

Water samples for physical and chemical parameters determination were collected from the river at monthly interval from April 2001 to June 2002. Phytoplankton samples were collected by towing $55 \mu \mathrm{m}$ mesh size plankton net against the current at subsurface level for ten minutes. The samples were preserved in a solution of four per cent formaldehyde. Phytoplankton samples were examined in the laboratory using a Leitz Orthoplan Universal Wide-Field Research microscope equipped with tracing and measuring devices. Identification and classification of phytoplankton were carried out with the aid of standard monographs and publications including Prescott (1975), Kadiri (1987) and Opute (1990, 1991, 2000 and 2003).

Conductivity and salinity were recorded with a $\mathrm{HACH}$ conductivity/salinity meter model CO150, dissolved oxygen was determined by the alkali-Azide modification of Winkler's technique, alkalinity was determined titrimetrically while nitrate was by the phenoldisulphonic acid method. Phosphate and silica were determined by the ascorbic acid and molybdosilicate methods respectively; as 
described by APHA (1998). Mean and standard error values were obtained for each of the physico-chemical parameters. SPSS statistical package was used to compute single factor ANOVA to test for differences in the sample stations.

\section{Results}

The phytoplankton of Imo river estuary was composed of 221 taxa classified into 7 divisions, 16 orders, 38 families and 85 genera. The composition of the flora is shown in Table 1 . About $49.8 \%$ of the total phytoplankton taxa belong to the division Chlorophyta. The bulk of these (about 84.5\%) are members of the order Zygnematales and the desmids constitute about $75.9 \%$ of the total green algae. The chlorophyta are most abundant in the freshwater zone of the estuary (Figure 1). The Bacillariophyta accounted for $38 \%$ of the total phytoplankton taxa, mainly Pennales (65.1\%) and the Centrales $35.9 \%$. Majority of the centrales appeared in the brackishwater zone while the reverse is the case for the pennales with majority of them found in freshwater zone of the estuary. The order of dominance of the families is; Naviculaceae >Diatomaceae >Surirrellaceae $>$ Nitzchiaceae $>$ Eunoticeae (Figure 2).

Members of the Cyanophyta made up $4.1 \%$ of the total phytoplankton and representative genera include Merismopedia, Anabaena, Oscillatoria and Spirulina and the Dinophyta accounted for 3.6\% of the total taxa and next to the Cyanophyta in proportion. The representative genera include Dinophysis, Peridinium, Protoperidinium and Ceratium. Dinophysis was the only freshwater dinophyta, while the other genera were found in brackishwater. The Euglenophyta had two representative genera Euglena and Phacus and accounted for $3.2 \%$ of the Imo River estuary phytoplankton. Euglena was found in freshwater while Phacus occurred in brackishwater. The Chrysophyta and Rhodophyta each contributed less than one per cent ( $0.9 \%$ and $0.4 \%$ respectively).Chrysophyta was represented by the genera Dinobryon and Synura while the Rhodophyta was represented 
by Batrachospermum and they were found in brackishwater and freshwater respectively.

Table 2 showd the range and mean values of some physico-physical parameters in the Imo River estuary. Water temperature values ranged from $25^{\circ} \mathrm{C}$ to $30^{\circ} \mathrm{C}$ with a mean value of $28 \pm 0.13^{\circ} \mathrm{C}$. $\mathrm{pH}$ values ranged from 5.2 to 8.2 with a mean value of $6.6 \pm 0.08$. Conductivity values, measured at ambient temperature, were between $15.3 \mu \mathrm{Scm}^{-1}$ and $39,780 \mu \mathrm{Scm}^{-1}$ (mean $6,993.85 \pm 996.04 \mu \mathrm{Scm}^{-1}$ ). Alkalinity values ranged from $12 \mathrm{mgl}^{-1}$ to $945 \mathrm{mgl}^{-1}$ (mean $38.77 \pm 7.89 \mathrm{mgl}^{-1}$ ). Recorded nitrate and phosphate values were between $0.004 \mathrm{mgl}^{-1}$ to $4.32 \mathrm{mgl}^{-1}$ and $0.01 \mathrm{mgl}^{-1}$ to $2.01 \mathrm{mgl}^{-1}$ respectively. Temperature, $\mathrm{pH}$ and phosphate were significant $(\mathrm{p}<0.05)$; alkalinity, conductivity, salinity and silica were highly significantly different $(\mathrm{p}<0.001)$, while dissolved oxygen concentration showed no significant difference ( $\mathrm{p}>0.05$ ) during the study period.

Table 3 showd the spatial distribution of phytoplankton found in the Imo River estuary into freshwater and brackish water species. The chlorophyta were exclusively found in freshwater and dominated by desmids. Species of Aulacoseira, Coscinodiscus, Cyclotella, Eunotia and Tabellaria occurred in both freshwater and brackishwater. Members of the cyanophyta, euglenophyta and rhodophyta occurred in the freshwater zone of the estuary while all dinophyta were found in the brackishwater except Dinophysis.

\section{Discussion}

The chemical composition, activity and the distribution of nutrients in estuary represent the end result of the meeting of normally dissimilar waters, those of rivers, streams and the sea. This is consequent upon the fluctuations associated with stream flood seasons and the flow of large quantities of freshwater, or with dry seasons when tidal flow of seawater dominates (John, 1986). The natural nutrient cycle can be disrupted however, by excessive nutrient loading from human sources such as wastewater or agricultural run offs. The added nutrients can support a higher phytoplankton population, producing algal blooms 
(Prowse \& Talling, 1958; Caljon, 1987; JiyalalRam, 1991). The Imo river estuary recorded high nutrient concentration as compared with other African rivers like River Niger (Kadiri, 1999b) and the Nile (Talling \& Rzoska, 1967); which were reported to be poor in nitrates, phosphate and sulphate but rich in chloride.

Apart from the major cations, anions and dissolved solids in water, gases were important chemical components of water. Their partial pressure and solubility in the waters (especially $\mathrm{CO}_{2}$ and $\mathrm{O}_{2}$ ) of streams and estuaries were major factors in determining the $\mathrm{pH}$ and alkalinity of water bodies and the high alkalinity values $\left(12 \mathrm{mgl}^{-1}-\right.$ $945 \mathrm{mgl}^{-1}$ ) of the Imo River estuary is an indication of its high buffering capacity. The nutrients essential for algal growth included cations like calcium, magnesium sodium and potassium, anions like sulphate, nitrate, phosphate and silica. Nitrate and phosphate were limiting nutrients whose concentrations in water influence phytoplankton growth and division (Ambasht and Ambasht 2005). Silica requirement was specific for diatoms and dinoflagellates due to its incorporation into their cell walls. The enormous volume of water entering tropical rivers during wet season can reduce chemical concentrations to potentially growth limiting levels for some algae (Nwankwo, 1994). In the present study, phytoplankton diversity was highest at the end of the wet season and early dry season. Similar event was observed by JiyalalRam (1991) in the Mahi estuary India; where at the time of appreciable high phytoplankton population nutrient concentrations were noticeably low indicating nutrient utilization.

A wide array of phytoplankton species was observed in this study and the brackish waters zone of the Imo river estuary exhibited high species density. Diatoms species like Eunotia asterionelloides, Ditylum brightwellii, and Coscinodiscus spp. were most abundant at near bloom proportion in the early dry season months. Spatial distribution of diatom taxa in estuary is dependent on the mixing and dispersion processes initiated when oceans and river waters meet 
(Akoma, 2004). The freshwater zone of the estuary (salinity <1\%o) showed more species diversity with the chlorophyta as most dominant group. The general order of dominance of the phytoplankton groups was:

chlorophyta $>$ bacillariophyta $>$ cyanophyta $>$ dinophyta $>$ euglenop hyta $>$ chrysophyta $>$ rhodophyta.

The population size and relative abundance of each species within a planktonic assemblage was a function of the differential abilities to survive and reproduce in the environment. Most diatoms were capable of surviving in the estuarine environment irrespective of the variable salinity (Nwankwo, 1998; Kadiri, 1999a). The chlorophyta (especially desmids) were less tolerant of salinity and were thus restricted to the freshwater zone of the estuary (Opute, 2000).

These factors in combination with inter and intra specific competitions and the relative ability of each algal group to take up, utilize, grow and multiply (exploit the environment) effectively gave rise to various algal assemblages. Periodic fluctuations in quantity and species composition were the characteristic features of phytoplankton in freshwater, brackish water and marine environments (Nwankwo, 1988). The peak of nutrient input did not coincide with the highest phytoplankton density and diversity in the Imo River estuary; as observed in this study. This was attributable to rainy season influx of nutrients from land drainage and the smoldering effect due to high turbidity and phytoplankton flushing. Similar observations were made in the Mahi estuary (JiyalalRam, 1991) and some Nigerian coastal waters (Kadiri, 1999a). Peak phytoplankton concentration was observed in November. With a dominant freshwater chlorophyta phytoplankton and wide array of salinity tolerant brackish water bacillariophyta species, the Imo Rivers estuary can be described as a tropical mesotrophic system. Season nutrient input and tidal effect of the adjacent ocean were important factors that determined the changes in the physico-chemical characteristics and phytoplankton composition of the estuary. 


\section{Conclusion}

This paper presented a preliminary investigation in an estuarine system in southern Nigeria. Unlike other rivers in the Niger Delta, the Imo River estuary is relatively pristine due to minimal oil exploratory and industrial activities. Changes in phytoplankton composition occur across the seasons while nutrient variation was a consequence of allochthonous input from natural sources and effects of ocean tides. The estuary water will require chemical treatment before it could be used for potable, industrial or agricultural irrigation. Also the estuary had great potential for aqua cultural and fisheries production owing to its abundant phytoplankton assemblages and content

\section{References}

Afinito, S., Fumanti, B. and Ricci, S. (1989). "Freshwater Algae from Kania" Sierra Leone: Revta Idiobiologica. 28: 167 - 178.

Akpan, E. R., Offem, J. O. and Nya, A. E. (2002). "Baseline Ecological Studies of the Great Kwa River, Nigeria I: Physico-Chemical Studies". African Journal of Enviromental Pollution \& Health 1(1): $83-90$.

Ambasht, R. S. and Ambasht, P. K. (2005). Environment and Pollution. (4th Ed). CBS Publishers. New Delhi.

APHA (1998). Standard Methods for the Examination of Water and Wastewater. (20th edition). Washington D.C.: American Water Works Association/Water Environment Federation.

Caljon, A. G. (1987). "A Recently Landlocked Brakishwater Lagoon of Lake Tangayika Physical and Chemical Characteristics, and SpatioTemporal Distribution of Phytoplankton" Hydrobiologia 153: 5570.

Edward, P. J. K. and Ayyakkanu, K. (1991). "Studies on the Ecology of Plankton Community of Kollidam Estuary, Southeast Coast of India: I. Phytoplankton.” Mahasagar 24: 89-97.

Jiyalalram, J. M. (1991). "Algae and Water Pollution in Mahi Estuary." Journal of Indian Fisheries Association. 21: 31 - 37.

John, D. M. (1986). "The Inland Waters of Tropical West Africa." Arch. Hydrobiologia 23: 1 - 244.

Kadiri, M.O. (1987). 'Algae And Primary Productivity Studies of The Ikpoba Reservoir”. Ph. D. Thesis University of Benin (unpublished). 
Kadiri, M. O. (1999a). "Phytoplankton Distribution in some Coastal Water of Nigeria." Nigerian Journal of Botany, 12(1): 51 - 62.

Kadiri, M. O. (1999b). 'A Spatial Profile of Net Phytoplankton in the Lower River Niger Recorded in the Wet Season.' Acta. Hydrobiologia 41: $247-258$.

Kadiri, M. O. (2002). "A Spectrum of Phytoplankton Flora along Salinity Gradient in the Eastern Niger Delta Area of Nigeria." Acta. Botanica Hungarica 44(1 - 2): 75 - 83.

Lee, R. E. (1989). Phycology. (2nd Ed.). New York: Cambridge University Press.

Mohammed, A. A., Ahmed, A. A. and Zainab, A. A. (1988). "Studies on Phytoplankton of the Nile System in Upper Egypt." Limnologica (Berlin) 17(1): $91-117$.

Nwankwo, D. I. (1998). "Seasonal Changes in Phytoplankton Composition and Diversity in the Epe Lagoon, Nigeria". Acta Hydrobiologia 40(2): $83-92$.

Nwadiaro, C. S. and Ezefili, E. N. (1986). 'A Preliminary Checklist of the Phytoplankton of New Calabar River, Lower Niger Delta.' Hydrobiological Bulletin. 19: $133-138$.

Odum, E. P. (1971). Fundamentals of Ecology. 3rd edition. Philadelphia: W.B. Sanders Company.

Opute, F. I. (1990). "Phytoplankton Flora of the Warri/Forcades Estuary of Southern Nigeria." Hydrobiologia 208: $101-109$.

(1991). "A Checklist of the Freshwater, Brackish and Marine Phytoplankton of the Warri/Forcados Estuaries of Southern Nigeria". Nigerian Journal of Botany. 4: 227 - 254. (2000). "Contribution to the Knowledge of Algae of Nigeria I.

Desmids from the Warri/Forcades Estuaries Part II. the Elongate Baculiform Desmids." Journal of Limnology. 59(2): 131 - 155.

(2003). Contribution to the knowledge of Algae of Nigeria. II. Chlorophyceae from the Warri/Forcados Estuaries Part I. the Orders Volvocales and Chloroccocales. Benin Sc. Dig. 1, 31 - 52

Pearl, H. W. (1988). "Nuisance Algae Blooms of Coastal Estuaries and Inland Waters." Limnological Oceanography 33, 823 - 847.

Prescott, G. W. (1975). How to know the Freshwater Algae. Dubuque, Iowa :

C. Brown Company Publishers.

Prowse, G. A. and Talling, J. F. (1958). 'The Seasonal Growth and Succession of Plankton Algae in the White Nile.' Limnological Oceanography 3, $223-238$. 
Phytoplankton and Nutrient Dynamics of a Tropical Estuarine System in Imo River...

Spiro, T. G. and Stigliani, W. M. (2003). Chemistry of the Environment. 2nd Ed. New Delhi : Prentice-Hall Inc.

Talling, J. F. and Rzoska, J. (1967). 'The Development of Plankton in Relation to Hydrobiological Regime in the Blue Nile'. Journal of Ecology. 65,637- 662.

Woodhead, N. and Tweed, R. (1958). 'A Check-list of Tropical West African Algae'. Hydrobiologia 11, 299 - 350. (1960). 'A Second Check-list of Tropical West African Algae (Fresh and Brackish Water).' Hydrobiologia 15, 225 - 286.

Figure 1 Phytoplankton Distribution in the Freshwater Zone of Imo River Estuary

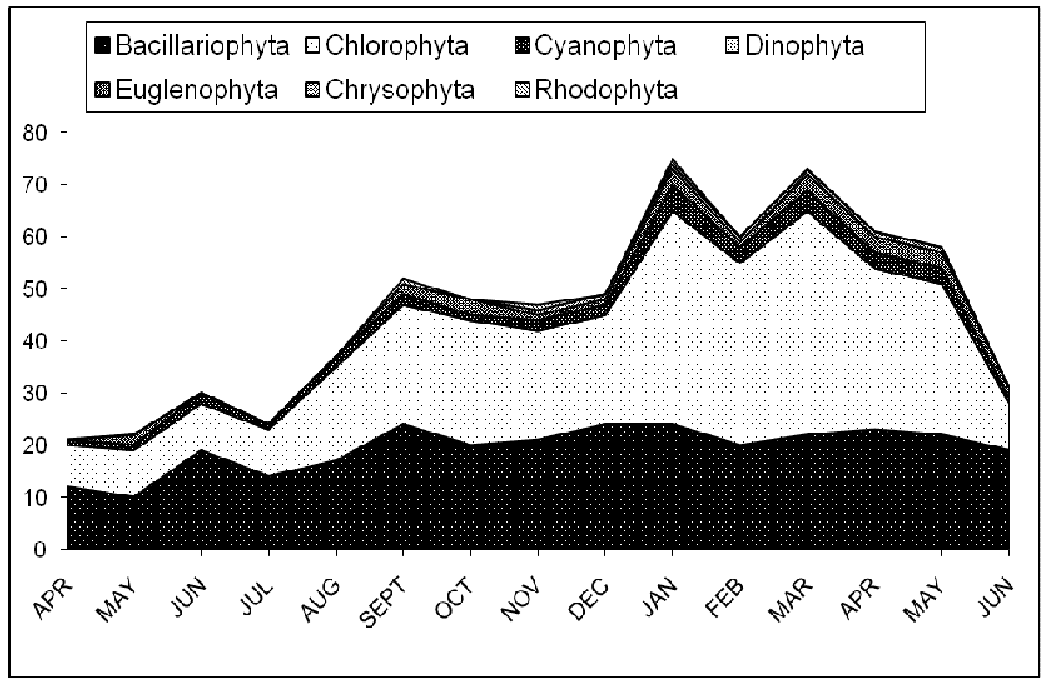


Figure 2: Phytoplankton Distribution in the Brackish water zone of Imo River Estuary.

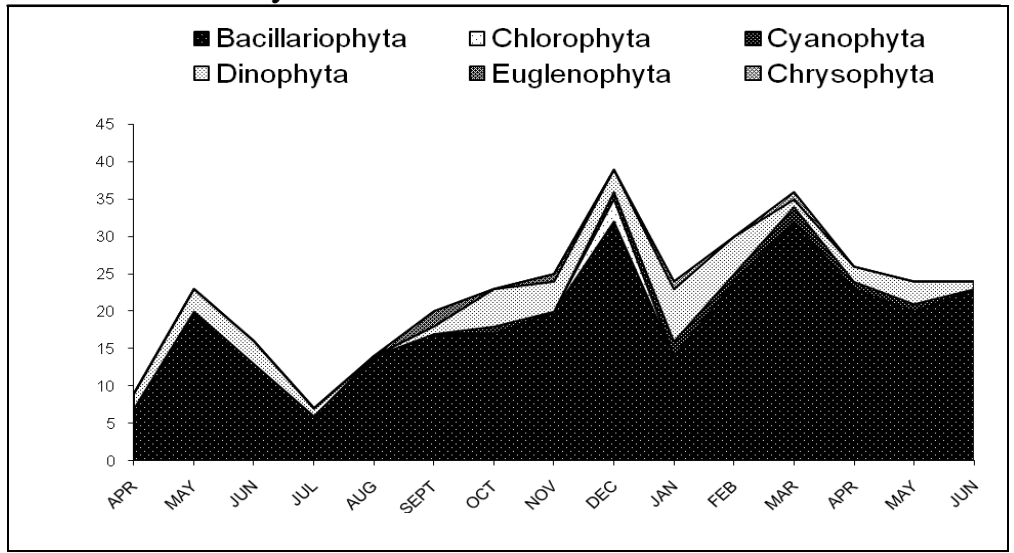

Table 1 Phytoplankton Composition of Imo River Estuary

\begin{tabular}{llllll}
\hline Divisions & Orders & Families & Genera & Taxa & \% Composition \\
\hline Bacillariophyta & 2 & 15 & 42 & 84 & 38 \\
Chlorophyta & 6 & 12 & 30 & 110 & 49.8 \\
Cyanophyta & 3 & 3 & 4 & 9 & 4.1 \\
Dinophyta & 2 & 3 & 4 & 8 & 3.6 \\
Euglenophyta & 1 & 1 & 2 & 7 & 3.2 \\
Chrysophyta & 1 & 2 & 2 & 2 & 0.9 \\
Rhodophyta & 1 & 1 & 1 & 1 & 0.4 \\
TOTAL & 16 & 37 & 85 & 221 & 100 \\
\hline
\end{tabular}


Phytoplankton and Nutrient Dynamics of a Tropical Estuarine System in Imo River...

Table 2 Summary of Physico-Chemical Properties of Imo River Estuary

\begin{tabular}{llll}
\hline Parameters & Range & Mean \pm S.E. & Probability \\
\hline Temperature ${ }^{\circ} \mathrm{C}$ & $25-30$ & $28 \pm 0.13$ & $\mathrm{P}<0.05$ \\
$\mathrm{pH}$ & $5.2-8.2$ & $6.60 \pm 0.08$ & $\mathrm{P}<0.05$ \\
$\begin{array}{l}\text { Conductivity } \\
\left(\mu \mathrm{Scm}^{-1}\right)\end{array}$ & $15.3-39,780$ & $6,993.85 \pm 996.04$ & $\mathrm{P}<0.001$ \\
$\begin{array}{l}\text { Alkalinity }\left(\mathrm{mgl}^{-1}\right) \\
\text { D. O. }\left(\mathrm{mgl}^{-1}\right)\end{array}$ & $12-945$ & $38.77 \pm 7.89$ & $\mathrm{P}<0.001$ \\
Salinity $(\% \circ)$ & $4.6-10.2$ & $7.26 \pm 0.11$ & $\mathrm{P}>0.05$ \\
Nitrate $\left(\mathrm{mgl}^{-1}\right)$ & $0-22 \%$ & $4.28 \pm 0.65$ & $\mathrm{P}<0.001$ \\
Phosphate $\left(\mathrm{mgl}^{-1}\right)$ & $0.01-2.01$ & $0.37 \pm 0.048$ & $\mathrm{P}<0.001$ \\
Silica $\left(\mathrm{mgl}^{-1}\right)$ & $0.25-27$ & $6.85 \pm 0.84$ & $\mathrm{P}<0.05$ \\
\hline
\end{tabular}

